\title{
The level and distribution of carbohydrases in the small intestine mucosa of pigs from 3 weeks of age to maturity
}

\author{
BY D. E. KIDDER AND M. J. MANNERS \\ School of Veterinary Science, University of Bristol, Langford House, Langford, \\ Bristol BSI8 $7 D U$
}

(Received 22 March 1979 - Accepted 5 July 1979)

1. The levels of the brush-border enzymes sucrase (sucrose glucohydrolase, EC 3.2.I.48), isomaltase (oligo-1,6-glucosidase, EC 3.2. I . I0), maltases 2 and 3 (glucoamylase, $E C$ 3.2 . I . 3), lactase ( $\beta$-galactosidase, $E C 3.2 .1 .23)$ and trehalase $(E C$ 3.2.1.28) and adsorbed pancreatic $\alpha$-amylase $(E C$ 3.2.1.I) have been measured at twenty-one positions along the small intestines of eighty-four pigs of different ages ranging from 3 weeks to 4.5 years. The state of dilation of the intestine at the sampling points was noted.

2. The levels of sucrase and isomaltase increased with age throughout the age-range studied. Trehalase and the glucoamylases increased with age up to 200-300 d of age. Lactase decreased with age over the whole age range.

3. For the pigs above 10 weeks of age, the distribution pattern of the brush-border enzymes along the intestine did not change with age. Each enzyme had a characteristic distribution curve, with low values at the proximal and distal ends and a peak which was proximal in the instance of lactase and trehalase and approximately mid-way along the gut with sucrase, isomaltase and the glucoamylases.

4. The pattern of distribution of the brush-border enzymes altered with age in the piglets, but approached the adult pattern by 8 weeks.

5. Piglets weaned at 3 weeks had higher levels of sucrase, isomaltase and glucoamylases at 5 weeks than piglets left on the sow. At 8 weeks of age the piglets weaned at 3 weeks still had higher sucrase and isomaltase levels than those on the sow.

6. There was a very close correlation between the sucrase and isomaltase levels, and between the maltase 2 and maltase 3 levels in all the samples, and a fairly close correlation between all these four enzymes.

7. The level of $\alpha$-amylase increased with age but showed no regular distribution pattern, its irregular fluctuations being related to the presence or absence of dilation of the intestine at the time of slaughter rather than to the position along the intestine.

Six different carbohydrases have been found in the brush border of the small intestine mucosa of the pig. They are lactase ( $\beta$-galactosidase, $E C_{3}$.2 . I .23), trehalase $(E C$ 3.2 I . 28) and four maltases ( $E C$ 3.2.1.20) (Dahlqvist, I $960 a, b, c, 196 \mathrm{I} a$ ) which are usually classified according to Dahlqvist (1962). Dahlqvist's maltase I a, with high activity towards isomaltose, is usually known as isomaltase (oligo-I,6-glucosidase, $E C$ 3.2.1.10), maltase $1 \mathrm{~b}$, the only one to hydrolyse sucrose, is usually called sucrase (sucrose glucohydrolase, EC 3.2. I.48), while maltases 2 and 3 , which are distinguished from one another by different heat sensitivity, are glucoamylases (EC 3.2.I.3).

The level of sucrase in pig small intestine mucosa has been shown to increase with age, and that of lactase to decrease (Bailey et al. 1956; Manners \& Stevens, 1972; Ekstrom et al. 1975), while trehalase and isomaltase were reported to be absent from the mucosa of a newborn pig (Dahlqvist, $196 \mathrm{I} b$ ). The distribution of sucrase and lactase along the intestine has also been examined at different ages (Manners \& Stevens, 1972; Ekstrom et al. 1975), and a limited study of the distribution of the other carbohydrases along the mucosa of the adult pig has been reported (Stevens \& Kidder, 1972).

However, the changes with age in level and distribution of the carbohydrases other than lactase and sucrase have not previously been studied in the pig or other species. As these are of consequence in assessing the age at which the digestive system reaches its full adult 
function, we have measured the six brush-border carbohydrases and the adsorbed pancreatic $\alpha$-amylase ( $E C_{3}$.2. I I) in the small intestine mucosa of pigs from 3 weeks to several years of age to see how the level and distribution of these enzymes varies with age, and the extent to which changes in level of one enzyme are correlated with those of another. Some of these results have been reported in preliminary communications (Kidder \& Manners, 1976, $1978 a, b)$.

\section{EXPERIMENTAL \\ Animals}

The animals used were of two classes: piglets (under ro weeks of age), and older pigs (over Io weeks). The thirty-five piglets were taken from twelve litters in a herd of a Landrace $x$ Large White cross breed. They were either left on the sow until slaughter at approximately 3,5 or 8 weeks of age, or weaned at 3 weeks and slaughtered at 5 or 8 weeks, giving five groups of piglets with seven animals in each group (Table 1 ). No group contained more than two piglets from any one litter. The weaning at 3 weeks was on to a commercial earlyweaning diet containing $(\mathrm{g} / \mathrm{kg})$ approximately 440 cereal products, 175 soya-bean meal, 225 dried milk products, 75 sucrose, $5^{\circ}$ fish meal. At $5^{-6}$ weeks this was gradually changed to a commercial growers' diet containing predominantly cereals with $(\mathrm{g} / \mathrm{kg}) 100-150$ extracted soya-bean meal and 25 fish meal. While on the sow, all the piglets had creep feed available from I week of age. This consisted of the early-weaning diet up to 5-6 weeks of age, when it was changed to the growers' diet.

The forty-nine older pigs came from three local herds, and were Large White, Landrace, British Saddleback, or crosses of these breeds. They were grouped according to age, with seven animals in each age group (Table 2).

\section{Slaughter and sampling}

The piglets were killed by injection of pentobarbitone sodium into the heart or vena cava. The older pigs were either stunned electrically or by the use of a captive bolt pistol and were then bled out. The body cavity was opened, the gut removed and the small intestine laid out on a calibrated plastic sheet.

The small intestine, especially in the older pigs, was often clearly divided into constricted regions, where the gut was almost closed with practically no luminal space, and dilated regions containing substantial quantities of digesta, fluid or gas. The extent of dilation was assessed subjectively as: 0 , fully constricted; I, slightly dilated; 2, fairly dilated; 3 , fully dilated, and the location of the regions of different extents of dilation recorded. Clips were then placed at positions corresponding to I and $5 \%$ of the distance from the pylorus to the ileo-caecal valve, further clips at positions corresponding to successive $5 \%$ intervals up to $95 \%$ of this distance and a final clip placed at $99 \%$ of the total distance. From these twenty-one positions, approximately $50 \mathrm{~mm}$ lengths of gut were taken, cut open, rinsed in chilled sodium chloride solution ( $9 \mathrm{~g} / \mathrm{l}$ saline), gently blotted, wrapped in aluminium foil, frozen in liquid nitrogen and then stored at $-20^{\circ}$.

The average time for completion of dissection and laying out of the small intestine on the cold dissection table was 19 min from the moment of slaughter. The average times from slaughter to transfer of all the samples to chilled saline and to liquid $N_{2}$ were 36 and $46 \mathrm{~min}$ respectively.

\section{Analysis}

The samples were allowed to thaw, approximately $0.2 \mathrm{~g}$ mucosa was scraped off with a blunt spatula and weighed accurately. An homogenate ( $10 \mathrm{~g} / 1$ saline) for enzyme and protein estimation was then prepared by sonication. 
Table I. Ages and weights of groups of piglets

\begin{tabular}{|c|c|c|c|c|c|c|c|c|}
\hline \multirow[b]{3}{*}{ Group } & \multicolumn{5}{|c|}{ Age } & & & \\
\hline & \multirow[b]{2}{*}{ Treatment } & \multirow{2}{*}{$\begin{array}{r}\text { Nominal } \\
\text { (weeks) }\end{array}$} & \multicolumn{3}{|c|}{ Actual (d) } & \multicolumn{3}{|c|}{ Wt (kg) } \\
\hline & & & Mean & SEM & Range & Mean & SEM & Range \\
\hline I & Sow & 3 & $21 \cdot 0$ & 0.5 & $19-22$ & 4.37 & 0.15 & $3 \cdot 7-4 \cdot 8$ \\
\hline 2 & Sow & 5 & 36.4 & 0.4 & $35-38$ & $8 \cdot 10$ & 0.82 & $5 \cdot 9-12 \cdot 2$ \\
\hline 3 & Weaned & 5 & 36.6 & 0.4 & $35-38$ & $8 \cdot 24$ & 0.69 & $5 \cdot 3-10 \cdot 1$ \\
\hline 4 & Sow & 8 & 57.9 & $1 \cdot 3$ & $56-59$ & 18.5 & $1 \cdot 3$ & $14.5-21.8$ \\
\hline 5 & Weaned & 8 & $57 \cdot 1$ & 1.6 & $55-59$ & $17 \cdot 6$ & 0.8 & $15 \cdot 5-21 \cdot 7$ \\
\hline
\end{tabular}

Table 2. Ages and weights of groups of older pigs

\begin{tabular}{|c|c|c|c|c|c|c|c|}
\hline \multirow[b]{3}{*}{ Group } & \multicolumn{4}{|c|}{ Age (d) } & & & \\
\hline & \multirow[b]{2}{*}{ Nominal } & \multicolumn{3}{|c|}{ Actual } & \multicolumn{3}{|c|}{ Wt (kg) } \\
\hline & & Mean & SEM & Range & Mean & SEM & Range \\
\hline 6 & 80 & 78.9 & 0.5 & $77-80$ & $28 \cdot 2$ & I.4 & $25 \cdot 0-34 \cdot 2$ \\
\hline 7 & 100 & IOI·I & $\mathbf{I} \cdot \mathbf{I}$ & 98-105 & $43 \cdot 2$ & $4 \cdot 4$ & $27 \cdot 2-52 \cdot 0$ \\
\hline 8 & 130 & I3I I I I & $4 \cdot 1$ & $116-143$ & $74 \cdot 6$ & $3 \cdot 8$ & $57-84$ \\
\hline 9 & 200 & $198 \cdot 3$ & $7 \cdot 2$ & $163-224$ & $102 \cdot 2$ & $7 \cdot 2$ & $73-126$ \\
\hline I0 & 400 & 397.9 & $17 \cdot 2$ & $356-458$ & 162.9 & II-I & $120-210$ \\
\hline II & 700 & 682.4 & $19 \cdot 2$ & $600-734$ & 188.5 & $3 \cdot 2$ & 178-204 \\
\hline 12 & 1500 & 1584.4 & 206.6 & $1003-2739$ & $234 \cdot 3$ & $17 \cdot 7$ & I $77-320$ \\
\hline
\end{tabular}

Protein was measured by the method of Lowry et al. (I95I) as adapted for the AutoAnalyzer by Rej \& Richards (1974). It was calculated as $\mathrm{mg}$ protein/g mucosal scraping.

Lactase was determined by the method of Kidder \& Manners (1975) using the modified Trinder reagent of Richardson (1977). Sucrase, isomaltase, glucoamylase and $\alpha$-amylase were measured by the methods of Kidder et al. (1972). Substrates and conditions of the determinations were as in Table 3. In the lactase assay, 4-chloromercuribenzoate was added to inhibit lactases other than the brush-border enzyme. Tris buffer $(0.2 \mathrm{M})$ was used in the $\alpha$-amylase determination to inhibit the glucoamylases. The homogenates for total glucoamylase determination were heated with EDTA at $55^{\circ}$ to destroy $\alpha$-amylase, and those for maltase 3 determination heated at $65^{\circ}$ to destroy $\alpha$-amylase and maltase 2 . Maltase 2 was taken to be the difference between total glucoamylase and maltase 3. Enzyme activities were calculated as $\mu \mathrm{mol}$ substrate split/min, this being interpreted for the dextran and starch substrates as $\mu \mathrm{mol}$ reducing sugar produced/min. The activity was then calculated per $\mathrm{g}$ protein.

\section{RESULTS}

Effect of age on brush-border enzyme level

With increasing age, the lactase levels decreased while those of all the other enzymes increased. The mean level for each enzyme for the twenty-one sites on each individual pig was calculated and plotted $v$. age, the age being on a logarithmic scale (Fig. I). In the instance of sucrase and isomaltase, this gave an almost linear plot, showing that the levels of these enzymes increased almost proportionately to log age over the entire age range studied. With maltase 2, maltase 3 and trehalase there was a similar increase up to 200-300 d of age. The mean lactase levels showed a fall with age. The regression lines for sucrase, isomaltase and lactase (Fig. I ( $a, b$ and $e$ )) have been calculated on the values from all the pigs. Those 
Table 3. Substrates and conditions of analysis for the enzymes

\begin{tabular}{|c|c|c|c|c|c|}
\hline Enzyme & Substrate (O.1 M) & Buffer & pH & Pre-treatment & $t$ of homogenate \\
\hline Lactase & $\begin{array}{l}\text { Lactose } \\
+4-C M B(0.09 \mathrm{~g} / 1)\end{array}$ & Phosphate $0.2 \mathrm{M}$ & $6 \cdot 0$ & & - \\
\hline Trehalase & Trehalose & $\begin{array}{l}\text { Phosphate } 0.2 \mathrm{M} \\
\text { +EDTA } 0.005 \mathrm{M}\end{array}$ & 6.0 & & - \\
\hline $\begin{array}{l}\text { Sucrase } \\
\text { Isomaltase }\end{array}$ & $\begin{array}{l}\text { Sucrose } \\
\text { Dextran* }\end{array}$ & & $\begin{array}{l}6.5 \\
6 \cdot 5\end{array}$ & & - \\
\hline Total glucoamylase & Soluble starch $\dagger$ & & 6.5 & $15 \min$ at $55^{\circ}+$ & +EDTA $0.005 \mathrm{M}$ \\
\hline $\begin{array}{l}\text { Maltase } 3 \\
\alpha \text {-Amylase }\end{array}$ & Potato starch (0.0IM) & Tris $0.2 \mathrm{M}$ & $\begin{array}{l}6.5 \\
7 \cdot 0\end{array}$ & $15 \min$ at $65^{\circ}+$ & $\begin{array}{l}\text { EDTA } 0.005 \mathrm{M} \\
-\end{array}$ \\
\hline
\end{tabular}

The molarity of the dextran and starch is with respect to glucose residues. Ltd)

* The dextran used was Dextran T10, a low molecular weight (approximately 10000) dextran (Pharmacia † The soluble starch was Merck (according to Zulkowsky) a degraded potato starch which will give a clear solution in cold water.

for the glucoamylases and trehalase (Fig. I $(c, d$ and $f)$ ) have been calculated on the pigs up to $250 \mathrm{~d}$ of age.

\section{Effect of treatment on brush-border enzyme level}

Comparing the sow-reared and early-weaned piglets, it is clear that, where differences existed, the levels were higher in the early-weaned piglets. Analysis of variance on these results showed very significant differences between the piglets on the two treatments in the sucrase and isomaltase levels at both 5 and 8 weeks and in the maltase 2 and maltase 3 levels at 5 weeks $(P<0.001$ in each instance). At 8 weeks there were no longer differences in the maltase 2 and maltase 3 levels between the sow-reared and early-weaned piglets. With trehalase, no treatment difference was found until 8 weeks of age, when the earlyweaned piglets had just significantly higher levels than those on the sow $(P<0.05)$. There was no difference in the lactase results between the two treatments. Regression analysis showed no significant difference in levels of any of the enzymes between different litters.

\section{Correlation of brush-border enzyme level with weight}

To see whether the levels of brush-border enzymes in the piglets were more closely related to age or to weight, they were regressed $v$. age, weight, log age and log weight. For all enzymes except trehalase, the correlations of enzyme level with log age and log weight were closer than with age and weight, and those with age or log age were marginally closer than those with weight or log weight, respectively. With trehalase there was a slightly better correlation of enzyme level with age than with log age, weight or log weight.

\section{Effect of sex and breed on brush-border enzyme levels}

There was no significant effect of sex on the level of any of the brush-border enzymes in either the piglets or the older pigs after the effect of age had been removed.

The piglets were all of the same cross, but the older pigs were of several breeds and crosses. With trehalase and lactase there was no significant effect of breed after the effect of age had been removed, but with sucrase, isomaltase, and particularly the two glucoamylases there was an effect, the Large Whites and Large White $\times$ Landrace crosses having significantly higher levels than the rest (Landrace, British Saddleback and Landrace $X$ British Saddleback crosses). 

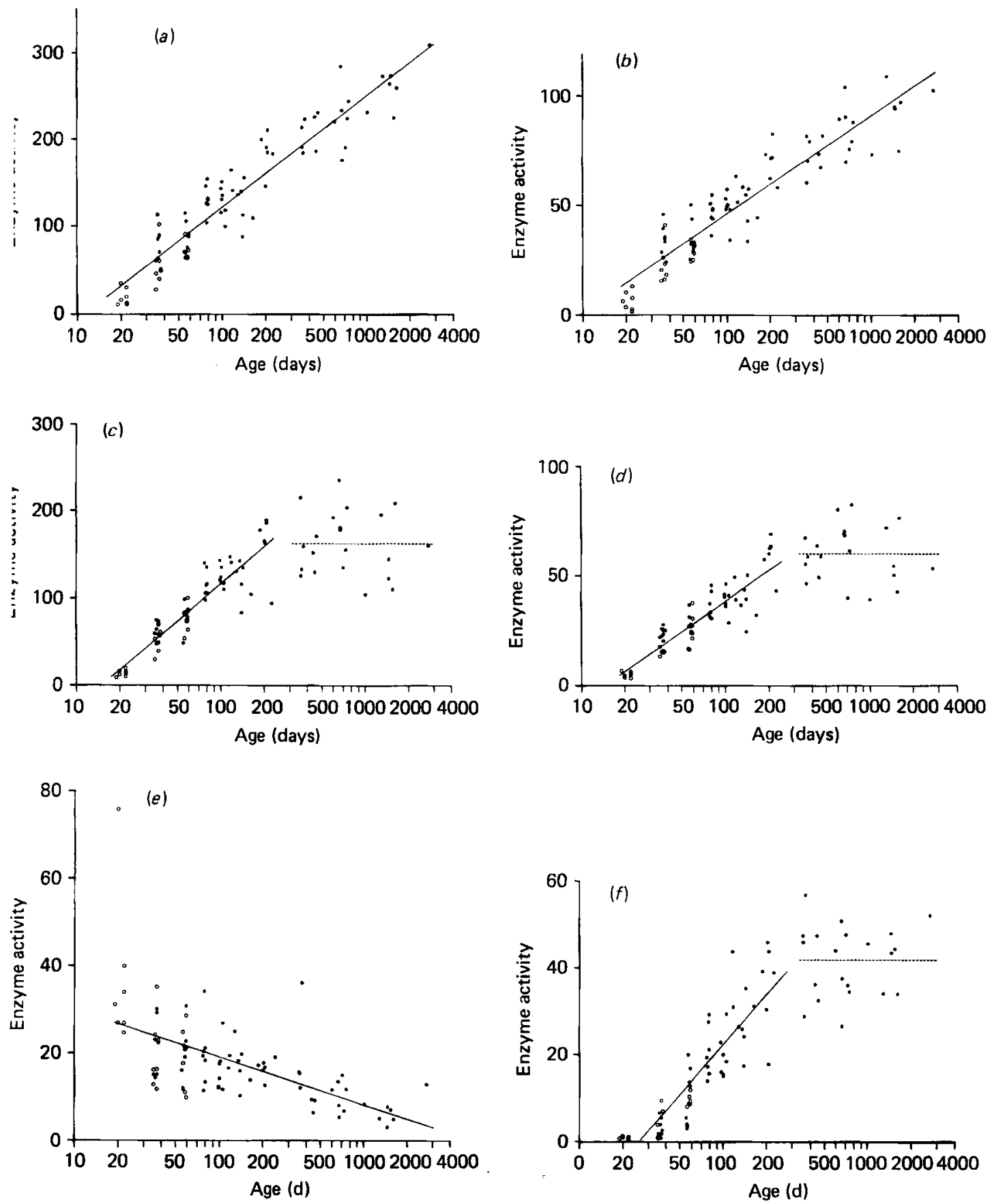

Fig. I. The mean brush-border enzyme activities (units/g protein) for the twenty-one samples from each of the eighty-four pigs plotted $v$. age, which is on a logarithmic scale. The enzyme activity is calculated as $\mu \mathrm{mol}$ substrate split/min per g protein. (a) Sucrase; (b) isomaltase; (c) maltase 2; $(d)$ maltase $3 ;(e)$ lactase; $(f)$ trehalase. $O$. Suckled pigs; $\bullet$, weaned pigs; - , regression line; -...-.-, mean value for groups $10-12(c, d$ and $f)$. The regression line in $a, b$ and $e$ is calculated on all pigs. In $c, d$ and $f$ it is calculated on the pigs of groups $1-9$. For details of groups, see Tables $I$ and 2. 


\section{Distribution of brush-border enzymes along the intestine}

Older pigs. Each of the brush-border enzymes (sucrase, isomaltase, maltase 2, maltase 3, lactase and trehalase) had a characteristic pattern of distribution along the small intestine which showed little alteration with age, in spite of the change of enzyme level with age. Fig. 2 shows the mean enzyme level for each position along the gut for each enzyme for the forty-nine older pigs. This illustrates the way each enzyme had a low level at the duodenal end, which rose to a peak and fell again at the distal end. The lactase and trehalase had a proximal peak while the four maltases had a peak approximately half-way along the small intestine. Only the glucoamylases and trehalase were present in more than trace amounts in the proximal $(1 \%)$ sample. The characteristic shape of the distribution curve of each enzyme was repeated in each of the seven age-groups. The level of the lactase curve became progressively lower with increasing age, the oldest group having a level just under half that of the $80 \mathrm{~d}$ group, while with all the other enzymes the level of the curve increased with age, that of the oldest group being a little more than double that of the $80 \mathrm{~d}$ group.

The variation in enzyme level between individuals within an age group was greater in these pigs for lactase than for the other enzymes (Table 4).

Piglets. The distribution pattern of the enzymes altered to some extent with age in the piglets. We have therefore presented the mean value for each enzyme for each position along the intestine for each of the age and treatment groups. Fig. 3 gives the mean values along the small intestine for the five groups of piglets for the six enzymes.

Except for lactase, the variation between individuals within a group was greater with the piglets than with the older pigs (Table 4). This was particularly so with the four maltases in the youngest piglets, due partly to the variable pattern of enzyme distribution along the gut at this age.

\section{Relationship in distribution between the enzymes}

Calculation of the correlation coefficients between the levels of the different enzymes for the 1764 mucosal samples (Table 5) showed an extremely close correlation between the sucrase and isomaltase levels and an almost equally close correlation between the maltase 2 and maltase 3 levels. These two pairs of enzymes were less closely, but nevertheless highly significantly, correlated with one another.

\section{$\alpha$-Amylase, protein and dilation}

$\alpha$-Amylase. The level of adsorbed pancreatic $\alpha$-amylase in the mucosal samples ranged from zero to 1002 units/g protein, the level varying erratically from one pig to another, and from one sample to the next in an individual pig. The only consistent trends were that the sample from the $1 \%$ position, close to the pylorus and to the exit of the pancreatic duct, had a much higher mean $\alpha$-amylase level $(P<0.00 \mathrm{I})$ than the rest, while the distal two samples (95 and $99 \%$ of length) had lower levels than the rest $(P<0.01)$. Fig. 4 shows the mean levels along the small intestine for eighty-four pigs. The $\alpha$-amylase level tended to be greater in older pigs, so that, in spite of the extremely erratic variations, it was equally and very significantly correlated with age and with log age $(P<0.001)$.

Protein. The protein levels were in the range $52-164 \mathrm{mg} / \mathrm{g}$ fresh mucosal scraping, varying more from one sample to another on an individual pig than between pigs. The only general trends (Fig. 4) were lower values in the most proximal $(1 \%)$ sample $(P<0.001)$, and a decline with age $(P<0.01)$.

Dilation. The mean distribution of regions dilated with contents, fluid and gas for the eighty-four pigs is also illustrated in Fig. 4. The distinction between the dilated and constricted regions was less clear-cut in the very young (3- and 5-week-old) piglets, especially 


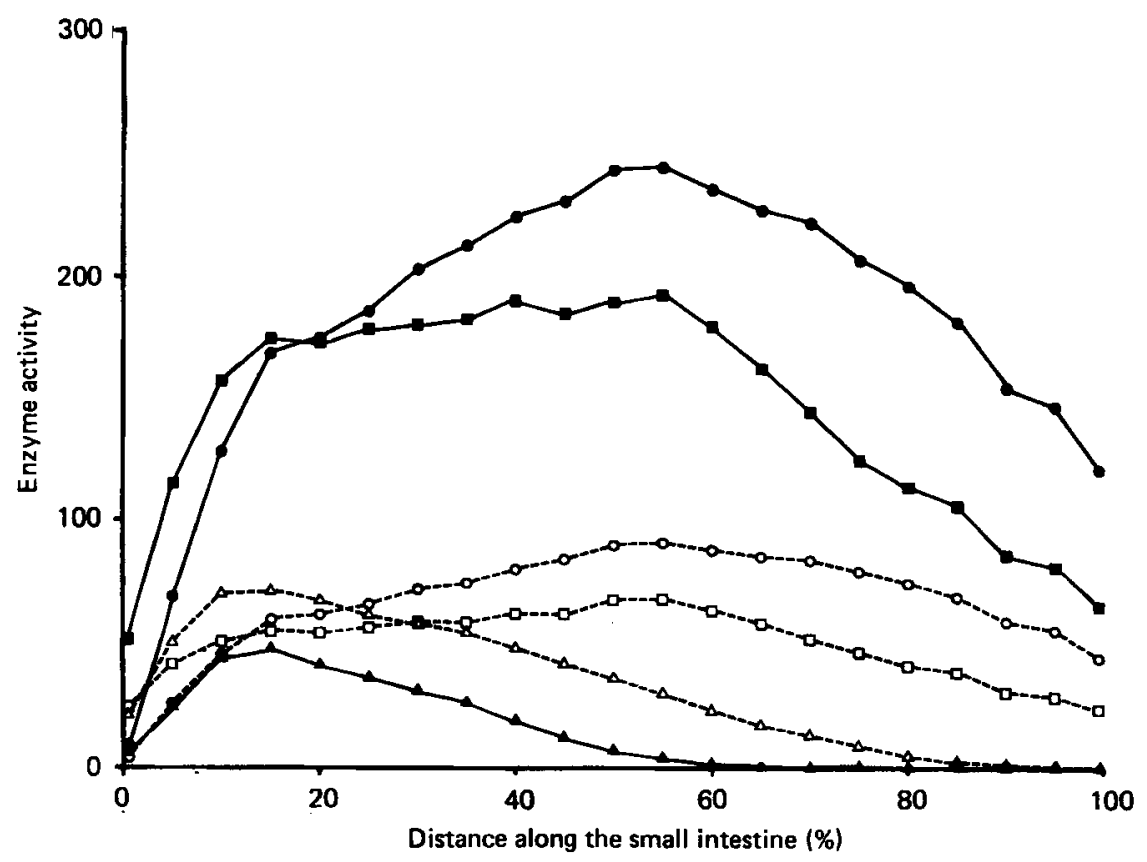

Fig. 2. The mean distribution of activity (units/g protein) of the six brush-border enzymes along the small intestine of the forty-nine older pigs. Each point is the mean of the forty-nine values for

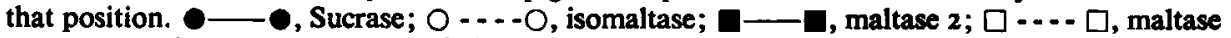
3; $\Delta-\Delta$. lactase; $\Delta \longrightarrow \triangle$, trehalase. The enzyme activities are calculated as $\mu$ mol substrate split/min per $\mathrm{g}$ protein.

Table 4. Coefficients of variation of enzyme levels at the same position along the intestine for different individuals within the same group of seven pigs

$\begin{array}{ccccccc}\text { Group* } & \text { Sucrase } & \text { Isomaltase } & \text { Maltase 2 } & \text { Maltase 3 } & \text { Lactase } & \text { Trehalase } \\ \text { I } & 0.639 & 0.836 & 0.460 & 0.473 & 0.618 & 0.695 \\ 2-5 & 0.406 & 0.388 & 0.290 & 0.324 & 0.521 & 0.953 \\ 6-12 & 0.250 & 0.255 & 0.310 & 0.313 & 0.695 & 0.418\end{array}$

* For details, see Tables I and 2.

in those on the sow. Otherwise there was no trend with age. The lower incidence of dilation in the 15,25 and $30 \%$ samples was highly significant $(P<0.01)$ and the higher incidence in the $75-90 \%$ samples was very highly significant $(P<0.001)$.

Relationship of $\alpha$-amylase, protein and dilation. What was noteworthy about the levels of $\alpha$-amylase and protein, and about the extent of dilation, was not any general trend, but the occurrence of striking fluctuations, usually involving all three of these measurements simultaneously. Samples from dilated regions usually had a relatively low protein and high $\alpha$-amylase, while samples from a completely constricted region usually had a high protein and an $\alpha$-amylase level which was never high and frequently was below the level of detection. These relationships are demonstrated by the correlation coefficients between the three measurements (Table 6). In dilated regions in the older pigs, the enzymes of the maltase group had depressions in their distribution curves comparable with results previously reported (Stevens \& Kidder, 1972; Kidder \& Manners, 1978a). 

I48
D. E. KIDder ANd M. J. Manners
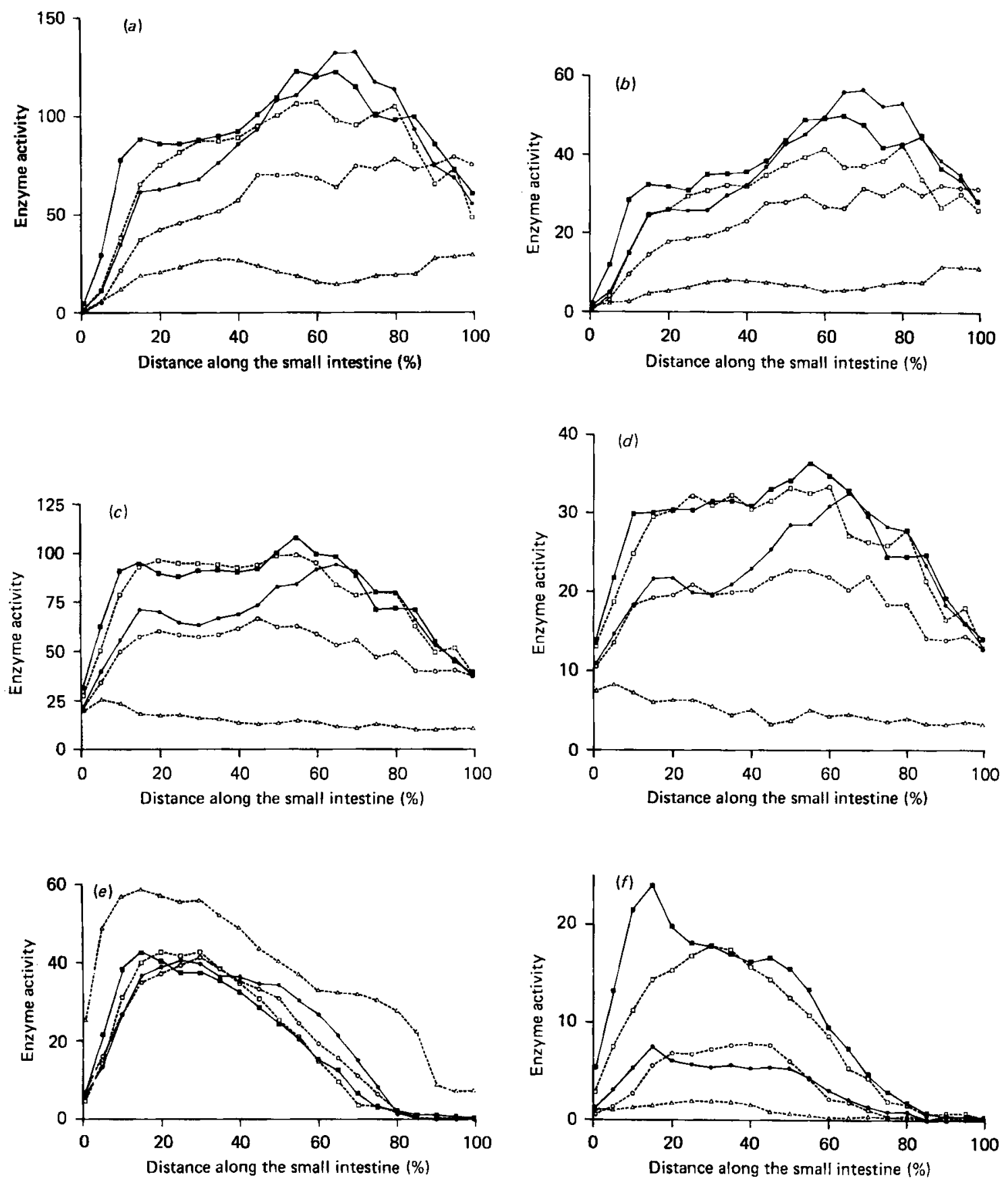

Fig. 3. The level (units/g protein) and distribution of brush-border enzymes along the small intestines of the five groups of piglets. Each point is the mean value for the seven piglets in the group. (a) Sucrase; $(b)$ isomaltase; $(c)$ maltase $2 ;(d)$ maltase $3 ;(e)$ lactase; $(f)$ trehalase. $\triangle \ldots .$.

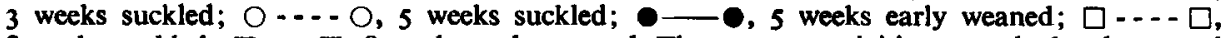
8 weeks suckled; $-\square, 8$ weeks early weaned. The enzyme activities are calculated as $\mu \mathrm{mol}$ substrate split/min per $\mathbf{g}$ protein. 
Table 5. Correlation coefficients between the enzyme levels in the 1764 mucosal samples

(df 1762)

$\begin{array}{lrrrrr} & \text { Sucrase } & \text { Isomaltase } & \text { Maltase 2 } & \text { Maltase 3 } & \text { Lactase } \\ \text { Isomaltase } & 0.983 & & & & \\ \text { Maltase 2 } & 0.822 & 0.824 & & & \\ \text { Maltase 3 } & 0.829 & 0.836 & 0.941 & & \\ \text { Lactase } & -0.197 & -0.243 & 0.018 & -0.081 & \\ \text { Trehalase } & 0.461 & 0.412 & 0.646 & 0.603 & 0.356\end{array}$

$P<0.05$ if $r>0.047, P<0.01$ if $r>0.06 \mathrm{I}, P<0.001$ if $r>0.079$.
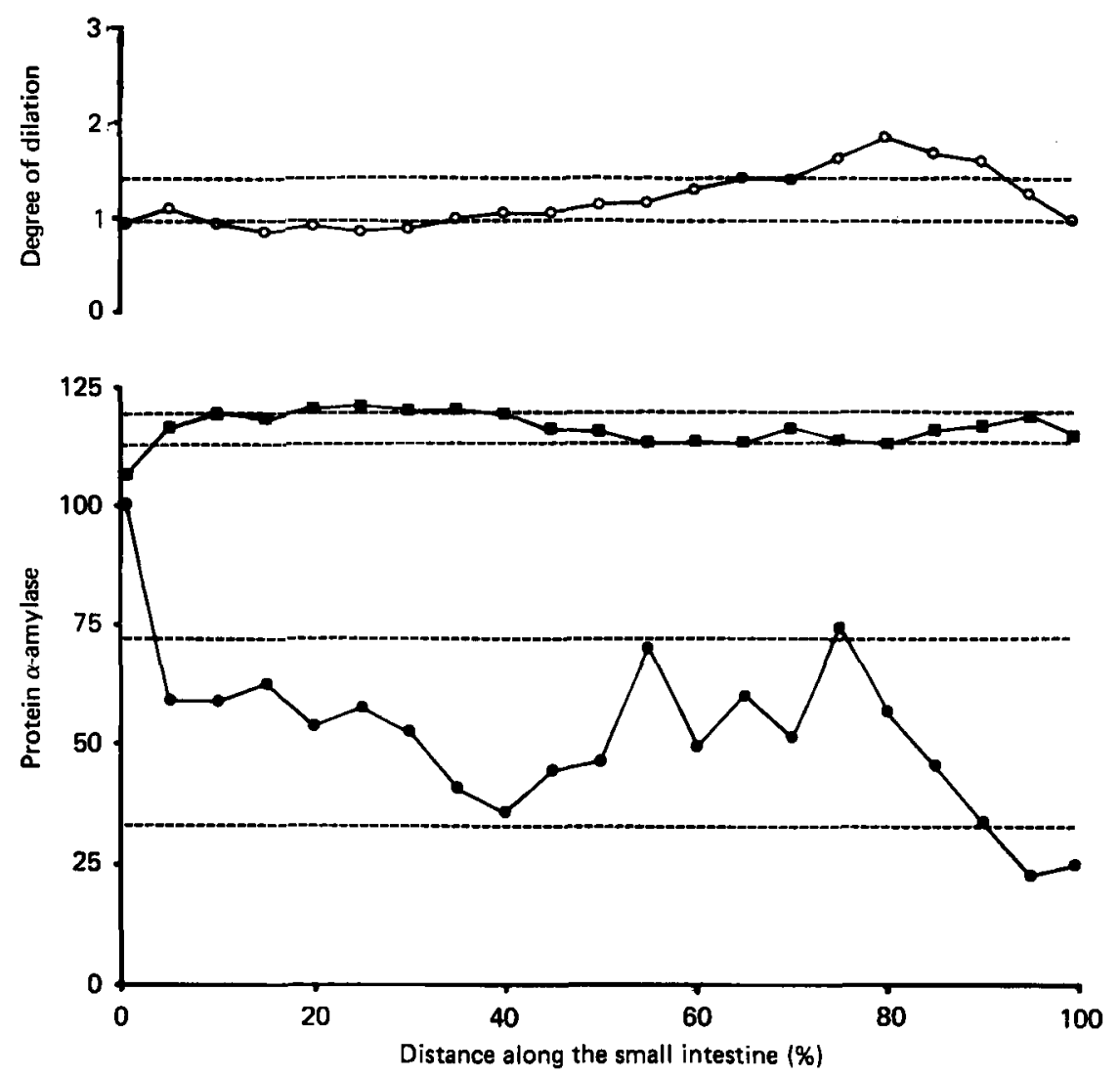

Fig. 4. The mean values along the small intestine of $\alpha$-amylase (units $/ \mathrm{g}$ protein), protein (mg/g tissue) and extent of dilation of the intestines of the eighty-four pigs. - $\alpha$-Amylase; m- - , protein; $O-O$, degree of dilation;..... . limits of significant difference of point from over-all mean $(P<0.05)$. The $\alpha$-amylase activity is calculated as $\mu \mathrm{mol}$ substrate split/min per 8 protein.

Because of the marked effect that age and position along the gut has on brush-border enzyme levels, a simple regression will not demonstrate the relationship between the levels of these enzymes and the extent of dilation of the gut. To overcome this problem, the effects of different pigs and different positions on brush-border enzymes, $\alpha$-amylase, protein and 
Table 6. Correlation coefficients for the relationships between dilation, $\alpha$-amylase and protein for the individual samples from the forty-nine older pigs

(df 1027)

$\begin{array}{lcc} & \text { Dilation } & \text { Protein } \\ \text { Protein } & -0.534 & - \\ \alpha \text {-Amylase } & 0.395 & -0.525 \\ P<0.001 \text { if } r>0.103 . & \end{array}$

extent of dilation were removed by analysis of variance. The adjusted values for the brushborder enzymes were then correlated with those of $\alpha$-amylase, protein and extent of dilation. The correlation coefficients (Table 7) show that, apart from trehalase, all the mucosal enzymes showed a very highly significant positive correlation with protein level and were significantly depressed in the dilated regions, the depression of the four maltases being very highly significant. The sucrase, isomaltase and maltase 2 all showed negative correlation with $\alpha$-amylase.

In each instance, the trehalase showed the opposite effect from the other brush-border enzymes, being elevated in the dilated regions. This is because the enzyme levels were calculated per $g$ protein, and in the dilated regions there had been protein loss. With trehalase the protein loss was presumably greater than the enzyme loss, whereas with the other enzymes the reverse was found.

\section{DISCUSSION}

\section{Sample preparation procedures}

The analysis was performed on mucosa scraped from washed intestine samples, and this is likely to have had different enzyme activity from mucosa in situ in a conscious pig. There will have been loss of mucosal cells, shedding of brush border and solubilization of enzyme into the gut lumen after slaugther and into the saline during rinsing and blotting. Expressing the results as activity/g protein rather than per $g$ tissue reduced the variability from sample to sample on individual pigs and will have reduced the effect of these losses. While these post-mortem changes will have affected the results on all the pigs and Stevens (1970) showed that, within the time limits achieved in the present work, the time taken over dissection did not materially affect the final measured mucosal enzyme levels, there are two factors which will have meant that all the results will not have been affected equally. Firstly, the method of slaughter was different for the piglets from that used for the older pigs. For this reason, and because the piglets were of different breeding from the older pigs, direct comparisons between the piglets and the older pigs have not been made except for looking at the change in enzyme level with age (Fig. I), where no discontinuity was observed between the two groups. Secondly, the concentrations of pancreatic enzymes and bile in the lumen may have been greater with increasing age and so caused more solubilization of mucosal enzyme between slaughter and sampling, particularly in the dilated regions of the intestine.

\section{Change in enzyme level with age}

The increase with age in the sucrase level in the younger pigs is in agreement with previous studies (Bailey et al. 1956; Walker, 1959; Manners \& Stevens, 1972). The continued increase after the pig has reached maturity, the similar increase in isomaltase, and the increase in trehalase and the glucoamylases up to $200 \mathrm{~d}$ of age have not previously been reported. These 
Table 7. Correlation coefficients for residuals from analysis of variance of the brush-border enzymes with pig and position as factors against similar residuals for dilation, protein and $\alpha$-amylase

\begin{tabular}{lcccccc} 
& \multicolumn{5}{c}{$(\mathrm{df}$ 1027) } \\
Dilation & Sucrase & Isomaltase & Maltase 2 & Maltase 3 & Lactase & Trehalase \\
Protein & -0.268 & -0.299 & -0.373 & -0.253 & -0.064 & 0.148 \\
$\alpha$-Amylase & 0.348 & 0.384 & 0.418 & 0.208 & 0.141 & -0.142 \\
& -0.093 & -0.136 & -0.168 & 0.046 & -0.038 & 0.122 \\
& $P<0.05$ if $r>0.061, P<0.01$ if $r>0.081, P<0.001$ if $r>0.103$. &
\end{tabular}

changes indicate that the digestive system continues to develop beyond the age at which many digestibility studies are carried out.

It is worth noting that correlation in the piglets of enzyme level with weight was no better than with age and, in most instances, was slightly worse. Weaning of piglets on reaching a given weight rather than a given age is often recommended on the basis that this will give a better indication of the state of maturity of their digestive system. Our evidence would not support this as far as mucosal carbohydrases are concerned.

The decline in lactase level with age is in agreement with previous studies on young pigs (Bailey et al. 1956; Walker, 1959; Manners \& Stevens, 1972) and on very many other mammals (e.g. de Groot \& Hoogendoorn, 1957). Manners \& Stevens (1972) found a very much steeper decline during the first few weeks of life than subsequently and reported a number of 3-week-old piglets with lactase levels similar to that of the one piglet in the present 3-week-old group with a lactase level a long way above the regression line (Fig. I (e)). It is probable that the lactase level is not, in fact, closely correlated with log age until after the age of 3 weeks.

\section{Effect of treatment}

Comparing the piglets weaned at 3 weeks with those left on the sow until slaughter, it is impossible to distinguish with any certainty between the effects of weaning per se and the effects of diet. As a result of weaning there will be a marked change in the composition, pH and bacterial flora of the luminal contents.

Where the enzyme levels were significantly different on the two treatments, those in the weaned piglets were higher, but marked differences were only found in the four enzymes of the maltase group. These differences in the maltase levels were all highly significant at 5 weeks and were still present at 8 weeks with the sucrase and isomaltase, but had almost disappeared with the glycoamylases. Specific increases in these enzymes have been induced in other species by substrate feeding (Deren et al. 1967; Rosensweig \& Herman, 1968). This could explain the much higher sucrase levels at 5 weeks, after 2 weeks on a diet containing $74 \mathrm{~g}$ sucrose $/ \mathrm{kg}$, and smaller differences at 8 weeks, when the diet for the previous 3 weeks did not contain sucrose. As the weaning diet was available to the sow-reared piglets as a creep feed, it is possible that the disappearance of the difference in glucoamylase levels by 8 weeks of age was due to increased consumption of starch-containing creep feed by the piglets on the sow.

\section{Effect of breed}

We have no information as to whether the breed differences observed with the glycoamylases relate only to the herds involved, nor whether, in view of the inducibility of these enzymes, such differences would occur on other feeding regimes. 


\section{Distribution of brush-border enzymes}

The distribution along the small intestine of sucrase and lactase reported in the present work agrees with that reported for the pig by Manners \& Stevens (1972) and Stevens \& Kidder (1972). The distribution of trehalase agrees with that reported by Stevens \& Kidder (1972) and our distribution of both glucoamylases agrees with that reported by these authors for total glucoamylase. Similar patterns of distribution of sucrase, lactase and trehalase have been found in other mammalian species.

The change of pattern in sucrase distribution with age in piglets studied here was similar to that reported by Manners \& Stevens (1972). In particular, in the present study a secondary peak in the sucrase level was present in six out of seven of our 3-week-old piglets, while Manners \& Stevens (1972) found a similar rise in five out of six of their 3-week- and four out of six of their 4-week-old piglets. A secondary distal peak in total maltase activity in 3-week-old piglets was reported by Tacu \& Bianu (1974).

The change in distribution of lactase with age in the piglets, with a gradual disappearance of the enzyme from the distal end, agrees with that reported by Manners \& Stevens (1972) and Ekstrom et al. (1975).

\section{Correlation of mucosal enzyme levels}

The strikingly close correlation between the sucrase and the isomaltase levels which was found throughout the study and was unaffected by the various factors which influence the levels of these enzymes (position along the gut, age, treatment, individual pig variation and effect of dilation), is in agreement with the finding (Kolinská \& Semenza, 1967) that a double molecule is present in mammalian brush border, one component of which is a sucrase and the other an isomaltase. The sucrase concerned is responsible for all the mucosal sucrase activity, and it is likely, on the basis of the correlation which we have found, that the isomaltase component is responsible for all or almost all the isomaltase activity which we have measured.

An almost equally close relationship was found between maltases 2 and 3, which seemed to be affected similarly by nearly all the causes of variation. In only one respect did they show a difference; maltase 2 was the enzyme most depressed in the dilated regions, while maltase 3 was the least affected of the four maltases. This difference, which perhaps relates to differences in sensitivity to inactivation, is probably responsible for the marginally lower correlation between maltase 2 and maltase 3 than that between sucrase and isomaltase, and would not exclude the possibility that the maltases 2 and 3 are bound together in a similar way to sucrase and isomaltase.

\section{Effect of dilation}

The clear-cut distinction observed in much of the small intestine of the pig at slaughter between constricted and dilated regions appears to be related to the batch-wise passage of food which has been observed in this species (Auffray et al. 1967; Laplace \& Tomassone, 1970). In regions where the intestine was dilated with contents or fluid at the time of slaughter, the protein content of the mucosal scrapings was lowered and the levels of the four maltases reduced to a much greater extent. There was also an increase in the amount of adsorbed $\alpha$-amylase.

These effects can be explained, on the basis of a number of studies in the rat, as due to recent exposure to digestive fluids. Adsorption of $\alpha$-amylase on to the small intestine mucosa and its disappearance after several hours non-exposure to pancreatic juice is well documented (Ugolev, 1960; Iezuitova et al. 1964; Alpers \& Solin, 1970), as is the relative 
absence of pancreatic enzymes from the lumen in the constricted regions of pig small intestine (Fossum \& Liven, 1974).

With regard to the reduction in enzyme levels, Alpers \& Tedesco (1975) showed that pancreatic juice and, in particular, the elastase it contained, caused the release of sucrase and other maltases, but not trehalase, from the mucosal surface. This would agree with the present findings. Maestracci (1976) confirmed this in the human small intestine. Vasseur et al. (1978) showed that bile salts caused release of proteins, sucrase and maltase from rat small intestine mucosa, and Eloy et al. (1978) brought about a similar release of protein and sucrase by perfusion of some peptide hormones in the absence of bile and pancreatic juice. It is clear that a number of components of digestive juices in the small intestine can bring about the release of proteins and of the maltase enzymes from the mucosal surface, some of this presumably occurring post mortem.

Thanks are due to Miss A. Norris, Mrs E. Glen and Mr K. Howard for technical assistance and to the staff of the slaughterhouse at the Meat Research Institute. We are also grateful to Dr S. Evans of the University of Bristol Computer Unit and Dr H. J. H. MacFie of the Meat Research Institute for assistance with the statistical analysis, and to RHM Agriculture Ltd for the piglets.

\section{REFERENCES}

Alpers, D. H. \& Solin, M. (1970). Gastroenterology 58, 833.

Alpers, D. H. \& Tedesco, F. J. (1975). Biochim. biophys. Acta 401, 28.

Auffrey, P., Martinet, J. \& Rérat, A. (1967). Annls Biol. anim. Bioch. Biophys. 7, 261.

Bailey, C. B., Kitts, W. D. \& Wood, A. J. (1956). Can. J. agric. Sci. 36, 5 I.

Dahlqvist, A. (1960a). Acta chem. scand. I4, 9.

Dahlqvist, A. (1960b). Acta chem. scand. I4, 1 .

Dahlqvist, A. (1960c). Acta chem. scand. r4, 72.

Dahlqvist, A. (1961 a). Biochim. biophys. Acta 50, 55.

Dahlqvist, A. (1961 b). Nature, Lond. rgo, 31.

Dahlqvist, A. (1962). J. clin. Invest. 4I, 463.

de Groot, A. P. \& Hoogendoorn, P. (1957). Netherlands Milk Dairy J. Ir, 290.

Deren, J. J., Broitman, S. A. \& Zamchek, N. (1967). J. clin. Invest. 46, 186.

Ekstrom, K. E., Benevenga, N. J. \& Grummer, R. H. (1975). J. Nutr. ro5, 1032.

Eloy, R., Vaultier, J. P., Raul, F., Mirhom, R., Clendinnen, G. \& Grenier, J. F. (1978). Res. exp. Med. r72, 109.

Fossum, K. \& Liven, E. (1974). Acta path. microbiol. scand. 382, 644.

lezuitova, N. N., de Laey, P. \& Ugolev, A. M. (1964). Biochim. biophys. Acta 86, 205.

Kidder, D. E., Hill, F. W. G. \& Stevens, J. A. (1972). Clin. Chim. Acta 38, 491.

Kidder, D. E. \& Manners, M. J. (1975). Clin. Chim. Acta 6r, 233.

Kidder, D. E. \& Manners, M. J. (1976). Proc. Nutr. Soc. 35, 26A.

Kidder, D. E. \& Manners, M. J. (I978a). Digestion in the Pig. Bristol: Scientechnica.

Kidder, D. E. \& Manners, M. J. (1978b). Proc. Nutr. Soc. 37, 3 I A.

Kolinská, J. \& Semenza, G. (1967). Biochim. biophys. Acta 146, 181.

Laplace, J.-P. \& Tomassone, R. (1970). Annls Zootech. I9, 303.

Lowry, O. H., Rosebrough, N. J., Farr, A. L. \& Randall, R. J. (195I). J. biol. Chem. 193, 265.

Maestracci, D. (1976). Biochim. biophys. Acta 433, 469.

Manners, M. J. \& Stevens, J. A. (1972). Br. J. Nutr. 28 , 113.

Rej, R. \& Richards, A. H. (1974). Analyt. Biochem. 62, 240.

Richardson, T. (1977). Annls clin. Biochem. 14, 223.

Rosensweig, N. S. \& Herman, R. H. (1968). J. clin. Invest. 47, 2253.

Stevens, J. A. (1970). Disaccharidase activity in the developing intestinal tract of the pig. MSc Thesis, University of Bristol.

Stevens, J. A. \& Kidder, D. E. (1972). Br. J. Nutr. 28, 129.

Tacu, A. \& Bianu, G. (1974). Nutritia Animalelor 3, 155.

Ugolev, A. M. (1960). Biul. eksp. Biol. Med. 49, I 2.

Vasseur, M., Ferard, G. \& Pousse, A. (1978). Pflügers Archiv. ges. Physiol. 373, 133.

Walker, D. M. (1959). J. agric. Sci., Camb. 52, 357. 